Mileu, N., \& Sargento, B. (2021). Is it possible to map wildfire susceptibility in Madeira Island? GeoFocus, Revista Internacional de Ciencia y Tecnología de la Información Geográfica (Artículos), 28, 5-23. http://dx.doi.org/10.21138/GF.692

\title{
IS IT POSSIBLE TO MAP WILDFIRE SUSCEPTIBILITY IN MADEIRA ISLAND?
}

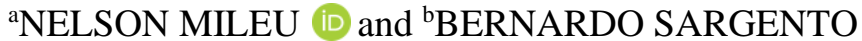 \\ Instituto de Geografia e Ordenamento do Território. Universidade de Lisboa \\ R. Branca Edmée Marques, 1600-276 Lisboa, Portugal \\ anmileu@campus.ul.pt, ${ }^{b}$ bernardosilva@campus.ul.pt
}

\begin{abstract}
This study focuses on wildfire susceptibility mapping in Madeira Island (Autonomous Region of Madeira, Portugal) and achieves this by using information value method and data processing in a Quantum Geographic Information System (QGIS) Plug-in programmed in Python. By means of a QGIS Plug-in a sensitivity analysis to the predisposition factors used in the construction of models of susceptibility to wildfires in Madeira Island was performed. For this analysis the burnt areas from 2006 to 2013 were related with some widely used variables in wildfire susceptibility modelling, namely land use, elevation, slopes, precipitation, humidity and temperature. The overall performance achieved by the information value method was assessed through success rate curves. The susceptibility models obtained with different combinations of variables present a very similar and unsatisfactory explanatory capacity. The different variable combination provided by the analysis demonstrated that land use and elevation play a major role in wildfire susceptibility explanatory capacity in Madeira Island. Additionally, the development of the QGIS Plug-in allowed to obtain quick and reliable results, proving to be extremely useful in the sensitivity analyses performed.
\end{abstract}

Keywords: wildfire; susceptibility; Madeira Island; climate change.

\section{É POSSÍVEL MAPEAR A SUSCETIBILIDADE A INCÊNDIOS NA ILHA DA MADEIRA?}

\section{RESUMO}

Este artigo procura analisar a suscetibilidade a incêndios florestais na Ilha da Madeira (Região Autónoma da Madeira, Portugal), com recurso ao método do valor informativo e ao processamento de dados através de um Plug-in do software Quantum Geographic Information System (QGIS) desenvolvido em Python. Através do Plug-in foi realizada uma análise sensitiva aos fatores de predisposição utilizados na construção do modelo de suscetibilidade a incêndios florestais na Ilha da Madeira. Esta análise baseouse na relação das áreas ardidas entre 2006 e 2013 e um conjunto de variáveis como o uso do solo, altitude, 


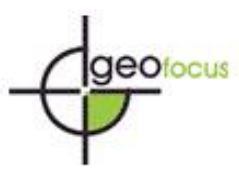

Mileu, N., \& Sargento, B. (2021). Is it possible to map wildfire susceptibility in Madeira Island? GeoFocus, Revista Internacional de Ciencia y Tecnología de la Información Geográfica (Artículos), 28, 5-23. http://dx.doi.org/10.21138/GF.692

declives, precipitação, humidade relativa e temperatura. A avaliação dos resultados para os diferentes modelos de suscetibilidade baseou-se nas curvas de sucesso, tendo-se verificado em todos uma baixa capacidade explicativa. As diferentes combinações de variáveis utilizadas na modelação da suscetibilidade demonstraram que variável uso do solo desempenha um papel relevante na capacidade explicativa da suscetibilidade a incêndios florestais na Ilha da Madeira. Adicionalmente, através do desenvolvimento do Plug-in do QGIS verificou-se que foi possível obter resultados de uma forma rápida e fiável, demonstrando-se o seu valor acrescentado na análise sensitiva realizada.

Palavras-chave: incêndios florestais; suscetibilidade; Ilha da Madeira; QGIS.

\section{Introduction}

With increasing human population and expanding land-use change, the interfaces between vegetation fires and vulnerable human assets are becoming more abundant, critical and conflicting (Goldammer, Ioannis, Mallinis \& Woolf, 2017), constituting the Madeira Island an example for this growing vulnerability. An important issue in the long wildfire history on the Madeira Island is to understand why some natural ecosystems and land-use systems are more adaptive or fire-tolerant than others highly susceptible ecosystems. The understanding and investigation of what may be the main driving factors inducing wildfires on the island of Madeira is fundamental. In this context, obtaining automated susceptibility maps assumes double importance for understanding what the main driving factors are. Wildfire susceptibility mapping can be defined as an estimation of the probability that fire occurs in a specific area without considering a temporal scale, assessed on the basis of predisposing factors related to terrain's intrinsic characteristics (Leuenberger et al., 2018). In this study, the adopted definition of wildfire susceptibility consists on the terrain propensity to suffer a wildfire or to support its spreading, given by the terrain's intrinsic characteristics (Verde and Zêzere, 2010) like slopes or land use.

An essential reference in the field of wildfire susceptibility mapping using GIS is the work of Chuvieco and Congalton (1989). The work was based on a qualitative model and the variables used were vegetation species, elevation, slope, aspect and proximity to roads and trails, campsites, or housing. Beyond qualitative and expert based methodologies, different statistical approaches have been used in wildfire susceptibility mapping, like logistic regression, used by Catry et al. (2010) or weights of evidence used by Romero-Calcerrada (2008) or Verde (2015). For the Portuguese mainland, several spatial distribution models of susceptibility explain the occurrence of wildfires (for example Pereira and Santos (2003); IGP (2007); Verde, 2008; Verde and Zêzere, 2010; Verde, 2015). However, in Madeira Island, excluding the work carried out under the regional forest management plan (DRFCN, 2015) and the regional civil protection emergency plan (SRPC, 2015), wildfire susceptibility models for Madeira Island are rare. In the small island context, González-Calvo et al. $(2007,2008)$ use satellite data and different static factors in the generation of a dynamic fire risk index for the Canary Islands (Spain). Regardless of the geographic context or the techniques used in the identification and combination of the predisposing variables, the use of GIS in processing and spatial analysis is common in these studies (Chuvieco et al., 2010; Chuvieco and Salas, 1996; Bonazountas et al., 2005; Jaiswal et al., 2002). A recent example in the use of open 


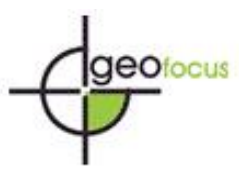

Mileu, N., \& Sargento, B. (2021). Is it possible to map wildfire susceptibility in Madeira Island? GeoFocus, Revista Internacional de Ciencia y Tecnología de la Información Geográfica (Artículos), 28, 5-23. http://dx.doi.org/10.21138/GF.692

source GIS software in data pre- and post-processing, and mapping elaboration, is the work of Leuenberger et al., 2018, dedicated to the comparison of two stochastic approaches in wildfire susceptibility mapping.

If the use of GIS in susceptibility mapping processes is common, the availability of tools that automate the process is less common. Although there are references to tools that automate the obtaining of susceptibility mapping (Jebur et al., 2015), their immediate availability in a repository and in open source is less common. In this work Information Value Method was the methodology used for modelling wildfire susceptibility mapping, supported by QGIS (QGIS Development Team, 2018) plug-in. The use of a QGIS plug-in for modelling wildfire susceptibility mapping is new and once the code is open source, it can be reused and enhanced by any user. The code is fully available on the GitHub platform through the following URL: https://github.com/BSargento/InformationValue-Plugin.

The aim of the paper is to evaluate the feasibility of obtaining wildfire susceptibility maps, supported by an easy-to-use GIS tool, performing a sensitivity analysis to the predisposition factors used in the construction of models of susceptibility to wildfires, using Madeira Island as case study. This analysis seeks to assess the variable combination with the best prediction capacity using a QGIS Plug-in programmed in Python (Python Software Foundation, 2018). It is expected that the development of the QGIS Plug-in will automate the extraction of the correlation among each class of conditioning factor and wildfire occurrence and reclassifies the factors using the calculated weights. With this tool it is expected to simplify the calculation of weights through a friendly interface and that the calculation time will be reduced, facilitating the improvement of model performance.

The paper is structured as follows: after introducing its aims in Section 1, an overview of the methodology, study area and the dependent and independent variables are presented in Section 2. Section 3 is concerned with the results namely the spatial variation of susceptibility and the model performance. The conclusions and specifications for further research are in Section 4.

\section{Materials and Methods}

\subsection{Study area}

The Madeira Island is part of an archipelago of volcanic origin located in the Southwest of Portugal mainland, in the eastern sector of the North Atlantic, between latitudes $32^{\circ} 36^{\prime}$ and $32^{\circ} 54^{\prime} \mathrm{N}$ and longitudes $16^{\circ} 38^{\prime} \mathrm{W}$ and $17^{\circ} 16^{\prime}$ (Figure 1). The Madeira Island has an area of $741.7 \mathrm{~km}^{2}$ and the land use is dominated by forest and other wooded areas (DRFCN, 2015). 


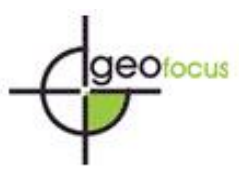

Mileu, N., \& Sargento, B. (2021). Is it possible to map wildfire susceptibility in Madeira Island? GeoFocus, Revista Internacional de Ciencia y Tecnología de la Información Geográfica (Artículos), 28, 5-23. http://dx.doi.org/10.21138/GF.692

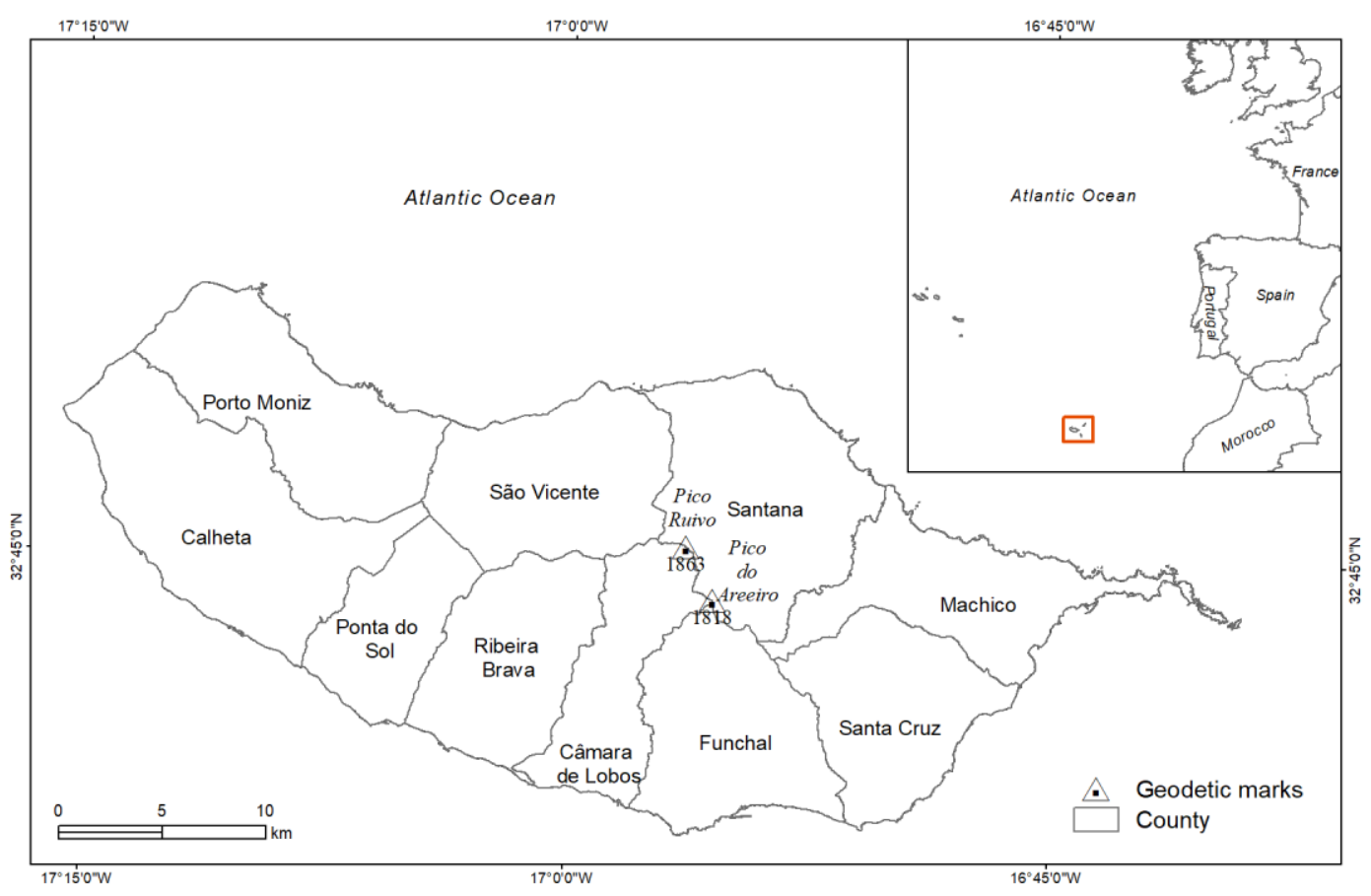

Figure 1. Location of Madeira Island and administrative divisions.

The Island of Madeira has a rugged relief, with the highest points being Pico Ruivo $(1,863 \mathrm{~m})$ and Pico do Areeiro $(1,818 \mathrm{~m})$. The relief, the soft weather, together with the exotic vegetation, are important attraction factors for tourism, the main activity of the region.

Since the fifteenth century several fires have been reported in the forests of the Madeira Island (Silva and Meneses, 1940). Over the years, forest fires on the Madeira Island have caused several negative consequences. For example, in August 2016, the media reported the death of three people, about 1000 evacuated and 150 houses were destroyed. The evolution of burnt area and number of wildfires in Autonomous Region of Madeira from 2000 to 2013 (Figure 2), obtained from Regional Directorate for Forestry and Nature Conservation (DRFCN, 2015), reveals that 2010 and 2012 wildfires affected $26 \%$ and $21 \%$ of the forested area in Madeira Island although the increase of the burned area is not associated to the number of ignitions (DRFCN, 2015). 


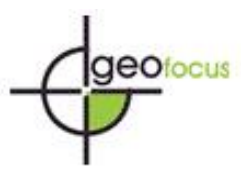

Mileu, N., \& Sargento, B. (2021). Is it possible to map wildfire susceptibility in Madeira Island? GeoFocus, Revista Internacional de Ciencia y Tecnología de la Información Geográfica (Artículos), 28, 5-23. http://dx.doi.org/10.21138/GF.692

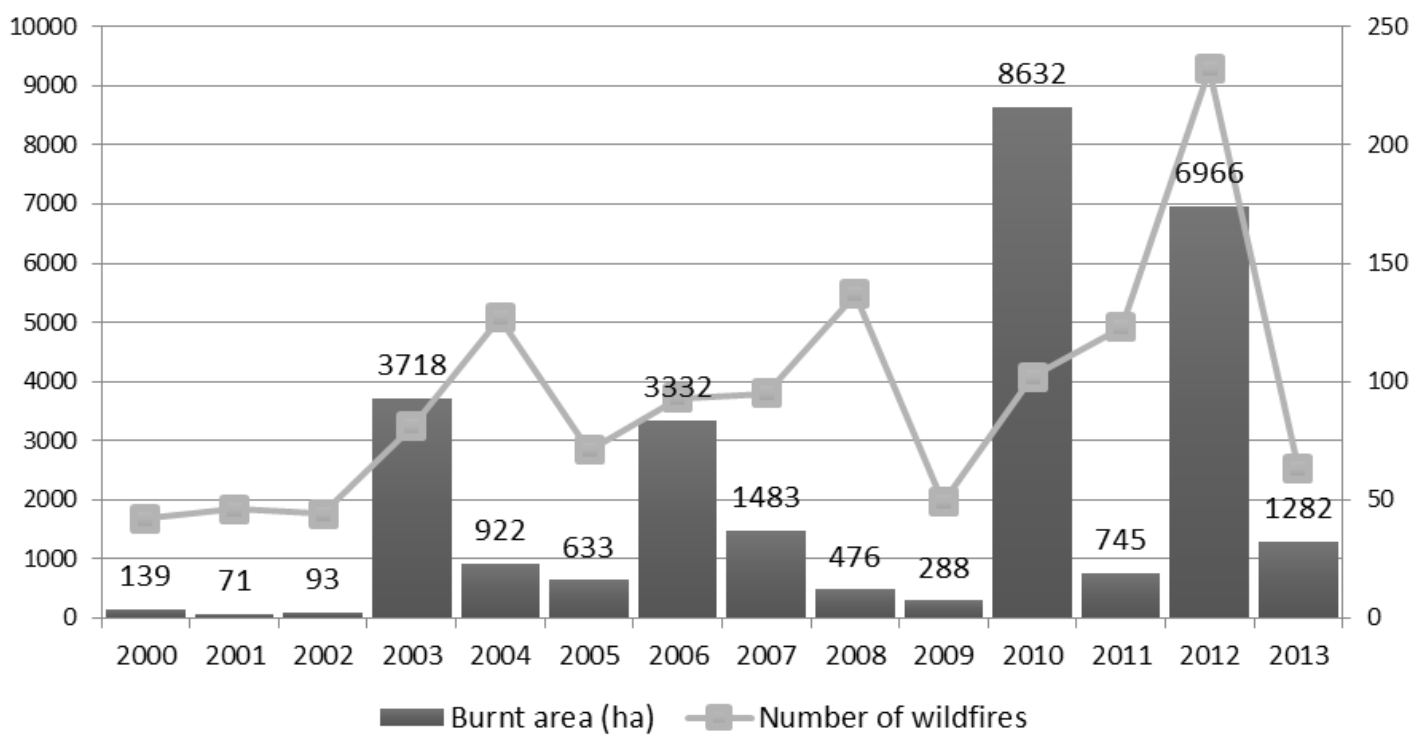

Figure 2. Evolution of burnt area and number of wildfires in Autonomous Region of Madeira from 2000 to 2013.

Source: DRFCN (2015).

\subsection{Overview of bi-variate GIS-based toolbox}

For the wildfire susceptibility assessment, the Information Value Method (Yin and Yan, 1988; $\mathrm{Wu}$, Yin and Liu, 2000) was used. This approach has been used in the assessment of other hazards, like landslides (Zêzere, 2002; Piedade, Zêzere, Garcia, \& Oliveira, 2011).

The pre-processing or transformation of initial raster layers for dependent and independent variables starts with the reclassification of the variables. This reclassification of variables results in a new raster layer where classes are identified in a field or attribute with the designation class ID (Table 1). The calculation of independent variable weights is based on the numeric values of the classes stored in the class ID field. The spatial resolution (pixel size) for the reclassified layers was 10 meters.

The next step is to obtain the favourability scores and then the weights for each class. The computation is based on the equation 1 and 2 explained in the next paragraphs. After this, the variables are reclassified based on the acquired weights and finally the susceptibility is calculated adding reclassified variables (Figure 3 ). 
Mileu, N., \& Sargento, B. (2021). Is it possible to map wildfire susceptibility in Madeira Island? GeoFocus, Revista Internacional de Ciencia y Tecnología de la Información Geográfica (Artículos), 28, 5-23. http://dx.doi.org/10.21138/GF.692

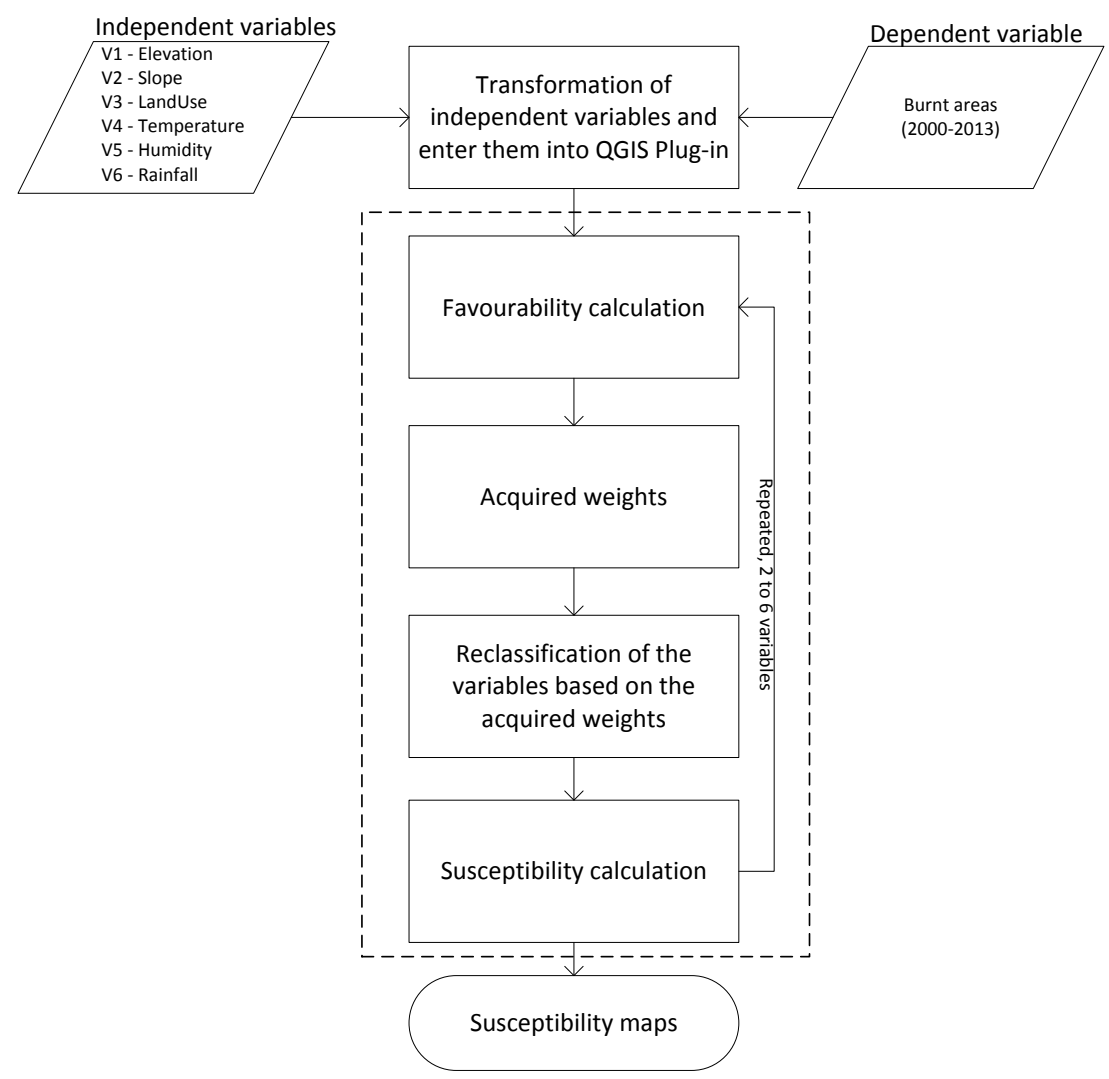

Figure 3. General methodology of wildfire susceptibility model.

Following Yin and Yan (1988) and Zêzere (2002), the information value Ii of each variable V1 to $\mathrm{V} 6$ is given by:

$$
\mathrm{Ii}=\log \frac{\mathrm{Si} / \mathrm{Ni}}{\mathrm{S} / \mathrm{N}}
$$

Where: $\mathrm{Si}=$ the number of terrain units representing burnt areas of type $\mathrm{V} 1$ to $\mathrm{V} 6, \mathrm{Ni}=$ the number of terrain units with variable $\mathrm{V} 1$ to $\mathrm{V} 6, \mathrm{~S}=$ the total number of terrain units representing burnt areas, $\mathrm{N}=$ the total number of terrain units.

The susceptibility map representing the total information value $\mathrm{Ij}$ for a terrain unit $\mathrm{j}$ is given by the formula:

$$
I j=\sum_{i=1}^{6} V j i i
$$

Where: $\mathrm{i}=$ number of variables used in this model; Vji=is either 0 or 1 if the variable is not present or present in the pixel $\mathrm{j}$; and $\mathrm{I}=$ information value of variable 
Mileu, N., \& Sargento, B. (2021). Is it possible to map wildfire susceptibility in Madeira Island? GeoFocus, Revista Internacional de Ciencia y Tecnología de la Información Geográfica (Artículos), 28, 5-23. http://dx.doi.org/10.21138/GF.692

Negative values of Ij mean that the presence of the different variables is not relevant to wildfire susceptibility. Instead positive values indicate a relevant relationship between the presence of the variable and the burnt areas distribution as described by Yin and Yan (1988) and Zêzere (2002).

Typically, the information value calculations are performed manually using a spreadsheet and geographic information system raster tools to reclassify rasters and to obtain the final susceptibility map. In this work, the aim is to perform a sensitivity analysis to the predisposition factors and several runs are required to obtain the variable combination with the best prediction capacity. Since it's a time consuming task, a QGIS plug-programmed in Python capable of calculating information value automatically was implemented. This tool automatically calculates the favourability among each class of conditioning factor and the burnt area, reclassifies the factors on the basis of the acquired weights in QGIS, and saves each correlation in separate folders. A simple graphical interface (GUI) was implemented to help the calculation of the different scenarios, without the need to perform repetitive tasks or any programming knowledge (Figure 4).

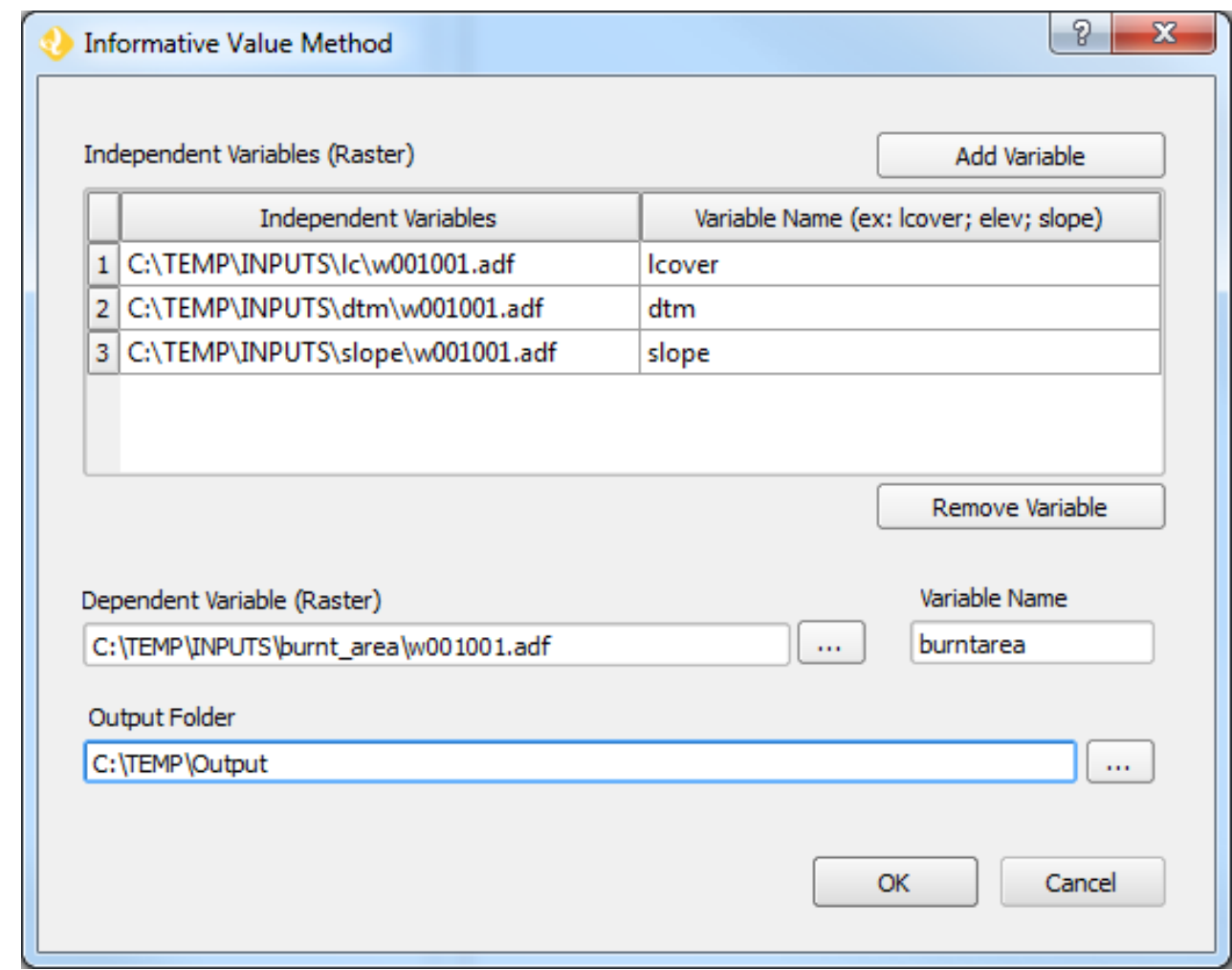

Figure 4. User Interface (GUI) of Informative Value Method Plug-in.

Supported by the Informative Value Method Plug-in, the wildfire susceptibility maps were obtained from five possible combinations among wildfire predisposing factors. 


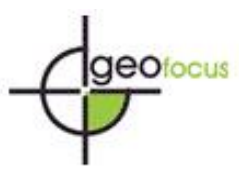

Mileu, N., \& Sargento, B. (2021). Is it possible to map wildfire susceptibility in Madeira Island? GeoFocus, Revista Internacional de Ciencia y Tecnología de la Información Geográfica (Artículos), 28, 5-23. http://dx.doi.org/10.21138/GF.692

In this study, the success curve approach was been used for validation (Frattini et al., 2010). The success curves were obtained from cross tabulation of burnt areas and the results of the models. The success rate (visually represented by a curve) shows how the model fits the data that was used to run it, but it does not allow the reader to make any consideration on the adequacy of the susceptibility map that the model creates, in regards to the future (Verde, 2015).

\subsection{Dependent variable}

The dependent variable used in the model consists in the burnt areas that occurred on the Madeira Island between the year 2006 and 2013, made available by the Regional Directorate of Forests and Nature Conservation (Figure 5). The burnt areas inventory map includes 273 total polygon features. Considering the reduced number of polygons and years of the time series, a validation sub-dataset wasn't deliberately extracted to test and compare the explanatory performances of the modelling results. The spatial distribution of the burned areas, between 2006 and 2013, identify the most prone areas, their dispersion in the space and the size of the areas affected by the fires in this period. In general, wildfires occur more frequently along the southern sector of the island, between the municipalities of Santa Cruz, Funchal, Câmara de Lobos, Ribeira Brava and Calheta. In the northern part of the island, although there are also some occurrences, they do not occur so frequently and so extensive.

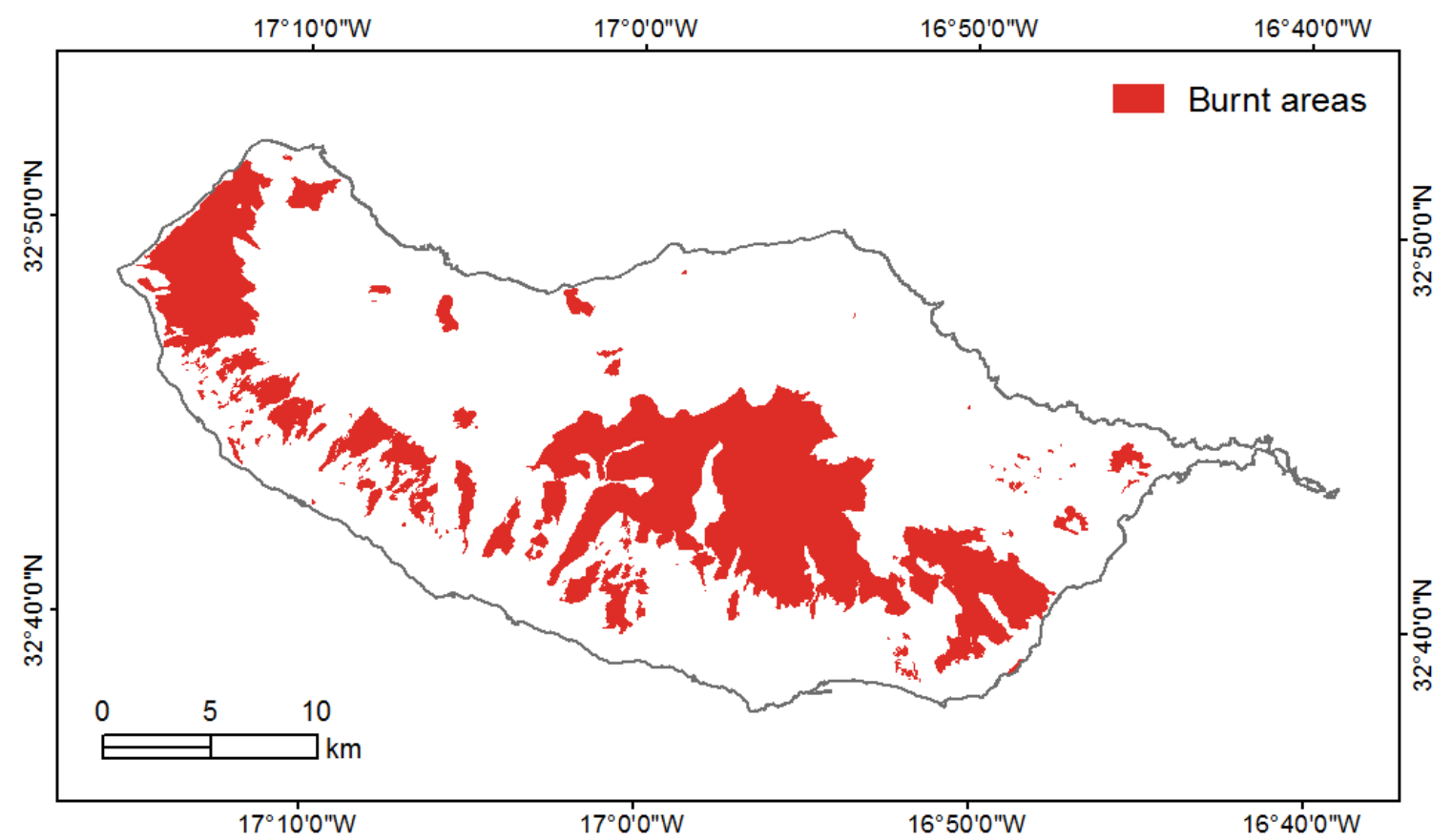

Figure 5. Burnt areas occurred on the Madeira Island between 2006 and 2013. 


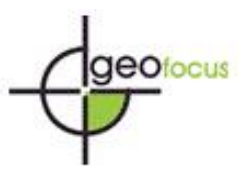

Mileu, N., \& Sargento, B. (2021). Is it possible to map wildfire susceptibility in Madeira Island? GeoFocus, Revista Internacional de Ciencia y Tecnología de la Información Geográfica (Artículos), 28, 5-23. http://dx.doi.org/10.21138/GF.692

\subsection{Independent variables}

Land use is one of the variables that most affects the occurrence of wildfires. In Madeira Island this variable has a particular importance because the strong representativeness of forest areas (around $80 \%$ of total area). Forests are mainly developed in the central island zone, being the littoral mostly occupied for artificial terrains and agricultural areas.

The land use thematic layer corresponds to the official Land Use Map of Autonomous Region of Madeira of 2007, made available by the Regional Directorate for Spatial Planning and Environment (DROTA). For the integration in susceptibility model, the most detailed characterization level (with 98 classes) was considered, although to facilitate the interpretation it was chosen to represent (in Figure 6 (a)) the theme aggregated in only 5 classes.

The influence of elevation in the wildfire occurrence is known, as reported by Ventura and Vasconcelos (2006) and Verde and Zêzere (2010) for the way it controls the meteorological factors such as the temperature, rainfall and relative humidity, which, in turn, influence the vegetation type and the amount of available fuel. Madeira Island has a fairly rugged relief, with very heterogeneous elevation values between the coast and the central zone of the island, where it reaches $1862 \mathrm{~m}$. The elevation theme used in the susceptibility model derives from the Digital Elevation Model (DEM), generated from the quoted points and the contours from the 2007 cartography at the 1: 5000 scale, made available by DROTA. The information was reclassified into 18 classes with a range of $100 \mathrm{~m}$ (Figure 6 (b)).

Madeira Island is characterized by abrupt cliffs and deep valleys with the quite high slopes. According to Verde and Zêzere (2010), "higher the slope, the faster fire progresses by heating of fuels uphill". The slope theme derives from DEM, made available by DROTA and was classified in 7 classes to integrate susceptibility model (Figure $6(\mathrm{c})$ ).

The selection of the meteorological variables and the analysed period was conditioned by the heterogeneous spatial distribution of the meteorological stations of the Madeira Island and by the irregularity of its operation. Due to the unavailability of climatological series with observations for a sufficiently long period, 9 meteorological stations were used records, from the Portuguese Institute of the Sea and the Atmosphere (IPMA), between 1999 and 2012. The average of daily records of relative humidity, the average of daily rainfall and the number of days with a maximum temperature equal to or greater than $25^{\circ}$, recorded in July, August and September, were interpolated with the Radial Basis Function and co-kriging methods available in QGIS software and then converted to raster for integration into the susceptibility model.

For all the factors, the classes were defined by the breaks observed in the histograms resulting from the cross tabulation of each variable with the burned areas. 


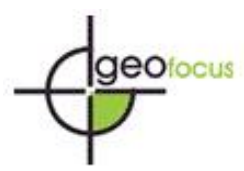

Mileu, N., \& Sargento, B. (2021). Is it possible to map wildfire susceptibility in Madeira Island? GeoFocus, Revista Internacional de Ciencia y Tecnología de la Información Geográfica (Artículos), 28, 5-23. http://dx.doi.org/10.21138/GF.692
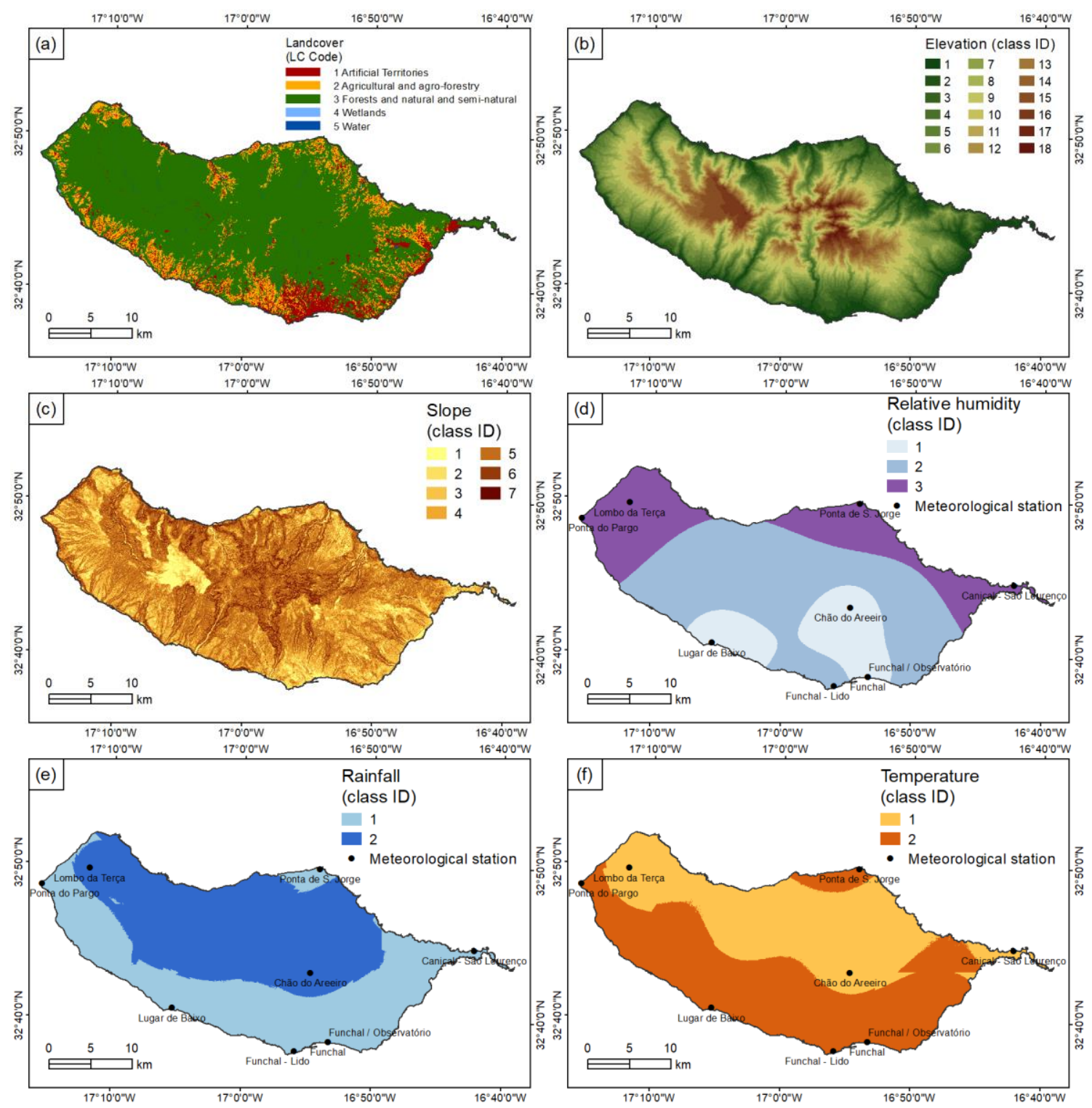

Figure 6. Maps of Independent variables (see legend in Table 1).

Table 1 presents for each independent variable the total number of pixels of the class, the total number of units burnt in each class and their respective favourability values. Due to the high number of land use classes, Table 1 lists only the classes with the highest favourability values. The most significant results are highlighted in the table with bold. It is important to mention the chestnut with coniferous forest and areas with an elevation above $1700 \mathrm{~m}$ which in the analysed period burnt in the totality. 
Mileu, N., \& Sargento, B. (2021). Is it possible to map wildfire susceptibility in Madeira Island? GeoFocus, Revista Internacional de Ciencia y Tecnología de la Información Geográfica (Artículos), 28, 5-23. http://dx.doi.org/10.21138/GF.692

Table 1. Thematic layers and favourability values of variables.

\begin{tabular}{|c|c|c|c|c|c|}
\hline $\begin{array}{c}\text { Class } \\
\text { ID }\end{array}$ & \multicolumn{2}{|c|}{ Thematic layer class } & $\begin{array}{c}\text { Number of } \\
\text { pixels in the } \\
\text { class }\end{array}$ & $\begin{array}{c}\begin{array}{c}\text { Number of burnt } \\
\text { pixels within the } \\
\text { class }\end{array} \\
\end{array}$ & \multirow[t]{2}{*}{ Favourability value } \\
\hline \multirow{2}{*}{\multicolumn{6}{|c|}{ Land use }} \\
\hline & & & & & \\
\hline 12 & 3 & Burnt Areas & 2227000 & 1355800 & 0.609 \\
\hline 15 & 1 & Landfills & 451200 & 256300 & 0.568 \\
\hline 21 & 3 & Clear cuts & 756600 & 204600 & 0.270 \\
\hline 32 & 3 & Chestnut open forest & 195900 & 129700 & 0.662 \\
\hline 35 & 3 & Eucalyptus open forest & 652500 & 562500 & 0.862 \\
\hline 36 & 3 & Eucalyptus and coniferous open forest & 123500 & 118300 & 0.958 \\
\hline 37 & 3 & Broad-leaved open forest & 75100 & 36200 & 0.482 \\
\hline 38 & 3 & Other coniferous open forest & 743900 & 300700 & 0.404 \\
\hline 39 & 3 & Pinus pinaster open forest & 4455000 & 3518200 & 0.790 \\
\hline 40 & 3 & Pinus pinaster with broad-leaved open forest & 848300 & 689500 & 0.813 \\
\hline 41 & 3 & Chestnut forest & 3622500 & 2011500 & 0.555 \\
\hline 42 & 3 & Chestnut with broad-leaved forest & 1064700 & 727200 & 0.683 \\
\hline 43 & 3 & Chestnut with coniferous forest & 197200 & 197200 & 1.000 \\
\hline 44 & 3 & Invasive species forest & 8478900 & 2299100 & 0.271 \\
\hline 47 & 3 & Eucalyptus forest & 30610400 & 15954200 & 0.521 \\
\hline 48 & 3 & Eucalyptus with broad-leaved forest & 15739100 & 4431700 & 0.282 \\
\hline 49 & 3 & Eucalyptus with coniferous forest & 8727700 & 4784400 & 0.548 \\
\hline 51 & 3 & Coniferous and broad-leaved mixture forest & 175900 & 136000 & 0.773 \\
\hline 52 & 3 & Other broad-leaved forest & 1191200 & 352300 & 0.296 \\
\hline 55 & 3 & Other coniferous forest & 4873500 & 1322500 & 0.271 \\
\hline 58 & 3 & Pinus pinaster forest & 24635900 & 11008100 & 0.447 \\
\hline 59 & 3 & Pinus pinaster with broad-leaved forest & 44125400 & 15372800 & 0.348 \\
\hline 60 & 3 & Pinus pinaster with coniferous forest & 313100 & 169400 & 0.541 \\
\hline 71 & 3 & Dense bushland and scrubland & 104001800 & 33090100 & 0.318 \\
\hline 72 & 3 & Low dense bushland and scrubland & 57931300 & 25232800 & 0.436 \\
\hline 73 & 3 & New plantations & 895300 & 262200 & 0.293 \\
\hline 78 & 2 & Permanent pastures & 1898300 & 640100 & 0.337 \\
\hline 80 & 1 & Quarries & 896200 & 279500 & 0.312 \\
\hline 94 & 3 & Sparce vegetation & 190800 & 83400 & 0.437 \\
\hline 95 & 3 & Natural herbaceous vegetation & 78561100 & 33316200 & 0.424 \\
\hline 98 & 2 & Forest-tree nurseries & 40000 & 11000 & 0.275 \\
\hline \multicolumn{6}{|c|}{ Elevation $(\mathrm{m})$} \\
\hline 1 & \multicolumn{2}{|c|}{$[0-100]$} & 39171400 & 791500 & 0.020 \\
\hline 2 & \multicolumn{2}{|c|}{ ] $100-200$ ] } & 45317200 & 2107300 & 0.047 \\
\hline 3 & \multicolumn{2}{|c|}{ ] $200-300$ ] } & 54441400 & 3937700 & 0.072 \\
\hline
\end{tabular}


Mileu, N., \& Sargento, B. (2021). Is it possible to map wildfire susceptibility in Madeira Island? GeoFocus, Revista Internacional de Ciencia y Tecnología de la Información Geográfica (Artículos), 28, 5-23. http://dx.doi.org/10.21138/GF.692

\begin{tabular}{|c|c|c|c|c|}
\hline $\begin{array}{l}\text { Class } \\
\text { ID }\end{array}$ & Thematic layer class & $\begin{array}{c}\text { Number of } \\
\text { pixels in the } \\
\text { class }\end{array}$ & $\begin{array}{c}\text { Number of burnt } \\
\text { pixels within the } \\
\text { class }\end{array}$ & Favourability value \\
\hline 4 & ] $300-400$ ] & 61174800 & 7519700 & 0.123 \\
\hline 5 & ] $400-500$ ] & 66892400 & 12765800 & 0.191 \\
\hline 6 & ] $500-600$ ] & 68161100 & 15716500 & 0.231 \\
\hline 7 & ] $600-700$ ] & 67873400 & 17677800 & 0.260 \\
\hline 8 & ] $700-800$ ] & 61484200 & 21535500 & 0.350 \\
\hline 9 & ] $800-900$ ] & 55828100 & 21178400 & 0.379 \\
\hline 10 & ] $900-1000$ ] & 47623500 & 18651100 & 0.392 \\
\hline 11 & ] $1000-1100$ ] & 41228900 & 14877400 & 0.361 \\
\hline 12 & ] $1100-1200$ ] & 36214000 & 12961900 & 0.358 \\
\hline 13 & ] $1200-1300$ ] & 30019300 & 11429800 & 0.381 \\
\hline 14 & ] $1300-1400$ ] & 22251300 & 9439100 & 0.424 \\
\hline 15 & ] $1400-1500$ ] & 23274300 & 9414600 & 0.405 \\
\hline 16 & ] $1500-1600$ ] & 15216100 & 6374400 & 0.419 \\
\hline 17 & ] $1600-1700$ ] & 3676600 & 3525900 & 0.959 \\
\hline 18 & $>1700$ & 1439100 & 1439100 & 1.000 \\
\hline \multicolumn{5}{|c|}{ Slope $\left(^{\circ}\right)$} \\
\hline 1 & {$\left[0-5^{\circ}\right]$} & 33847900 & 3252000 & 0.096 \\
\hline 2 & ] $\left.5-10^{\circ}\right]$ & 58252200 & 9301300 & 0.160 \\
\hline 3 & ] $\left.10-15^{\circ}\right]$ & 76941400 & 14876600 & 0.193 \\
\hline 4 & ] $\left.15-25^{\circ}\right]$ & 159520900 & 39070900 & 0.245 \\
\hline 5 & ] $\left.25-45^{\circ}\right]$ & 308498100 & 93403200 & 0.303 \\
\hline 6 & ] $\left.45-65^{\circ}\right]$ & 90722700 & 26458900 & 0.292 \\
\hline 7 & $>65^{\circ}$ & 13503900 & 4980600 & 0.369 \\
\hline \multicolumn{5}{|c|}{ Relative humidity (\%) } \\
\hline 1 & $<70$ & 130873700 & 55907600 & 0.427 \\
\hline 2 & $70-73$ & 396352400 & 96916200 & 0.245 \\
\hline 3 & $>73$ & 214061000 & 38519700 & 0.180 \\
\hline \multicolumn{5}{|c|}{ Rainfall (mm) } \\
\hline 1 & $\leq 1$ & 340905200 & 90144300 & 0.264 \\
\hline 2 & $>1$ & 400381900 & 101199200 & 0.253 \\
\hline \multicolumn{5}{|c|}{ Temperature $\left({ }^{\circ} \mathrm{C}\right)$} \\
\hline 1 & $\leq 40$ & 343644700 & 83569800 & 0.243 \\
\hline 2 & $>40$ & 397642400 & 107773700 & 0.271 \\
\hline
\end{tabular}

The correlation matrix for all the independent variables show low correlations. Despite showing low correlations, the relationships between the number of days with a maximum temperature equal to or greater than $25^{\circ}$ and the average of daily rainfall, and elevation and average 


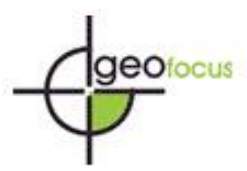

Mileu, N., \& Sargento, B. (2021). Is it possible to map wildfire susceptibility in Madeira Island? GeoFocus, Revista Internacional de Ciencia y Tecnología de la Información Geográfica (Artículos), 28, 5-23. http://dx.doi.org/10.21138/GF.692

of daily records of relative humidity stand out. These not significant values demonstrate the inexistence of collinearity, neither affecting the interpretation of the susceptibility model nor its predictive capacity.

\section{Results and Discussion}

\subsection{Information value of predisposing factor classes}

The informative value method uses scores to evaluate the relationship between each class of independent variables and the burnt areas (dependent variable). Figure 7 shows the informative values obtained for each class of variable, where the highest informative values correspond to the classes that contribute most for the explanation of burnt areas and the negative values indicate a weak relation between each class of the variable and the burnt areas, that is, they have little control over the dependent variable. Thus, it is verified that the occurrence of fires is favoured in areas of chestnut with coniferous forest, eucalyptus and coniferous open forest, pinus pinaster with broadleaved open forest, with elevations above $700 \mathrm{~m}$ (with a higher incidence above $1600 \mathrm{~m}$ ) and slopes higher than $25^{\circ}$ (with a higher incidence above $65^{\circ}$ ). Regarding the influence of the meteorological variables, it is verified that in areas where rainfall is less frequent, relative humidity is lower and the air temperature higher, susceptibility to the wildfire is more favoured.
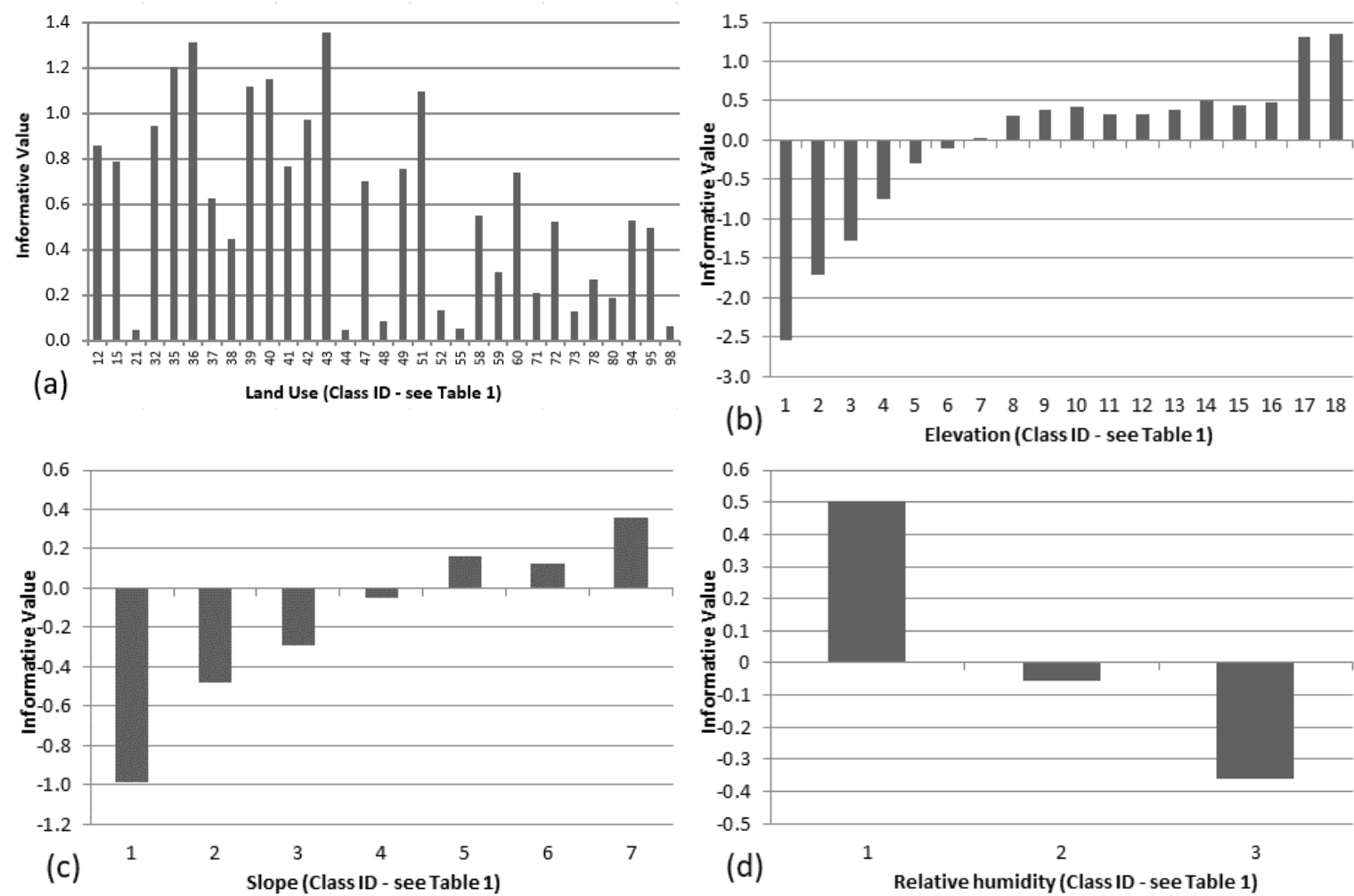


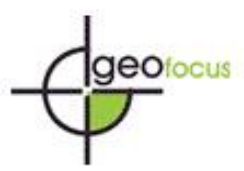

Mileu, N., \& Sargento, B. (2021). Is it possible to map wildfire susceptibility in Madeira Island? GeoFocus, Revista Internacional de Ciencia y Tecnología de la Información Geográfica (Artículos), 28, 5-23. http://dx.doi.org/10.21138/GF.692
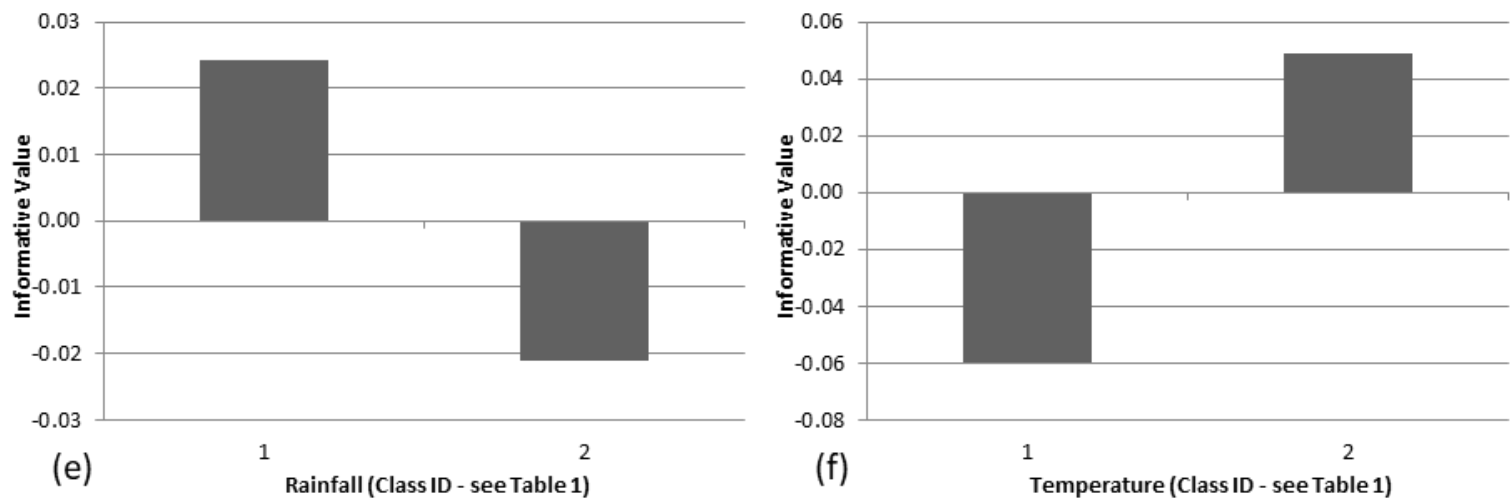

Figure 7. Information Value of predisposing factor classes.

\subsection{Performance assessment}

The integration of independent variables in the model was done progressively based on a sensitive analysis, in witch was defined a hierarchy of predisposition factors from the Areas Under Curve (AUC) obtained in the models produced individually. AUC are a useful indicator of which curve behaves the best (Verde, 2015), and are represented in percentages.

The Land Use is the variable that individual presents the greatest explanatory capacity, with a success rate around 0.684 (Table 2). In the second model (M2) were introduced the elevation variable, followed by slopes (M3), relative humidity (M4), rainfall (M5) and the temperature (M6). The introduction of the variables in the model did not significantly improved their explanatory capability (success curves with AUC always under 0.75), with a slight reduction with the introduction of temperature variable (M6).

Table 2. AUC for success rates, for the total set of wildfire susceptibility models.

\begin{tabular}{clc}
\hline Model & Variables & AUC \\
\hline M1 & LC & 0.684 \\
M2 & LC + E & 0.718 \\
M3 & LC + E + S & 0.729 \\
M4 & LC + E + S + H & 0.732 \\
M5 & LC + E + S + H + R & 0.733 \\
M6 & LC + E + S + H + R + T & 0.732 \\
\hline
\end{tabular}

The success curves showed in Figure 8 confirms the weak explanatory capability of the susceptibility models $($ AUC $<0.8)$ and the slight differences with the introduction of more variables. The success rate (graphically represented by the five curves) shows how the model fits the data that was used in the different models (M2, M3, M4, M5 and M6).Visually it is hard to distinguish the contributions of each variable in the models given the similarity of success curves. Only in the model produced with 2 variables (land use and elevation) it is possible to distinguish a lower performance, and it is verified that up to $40 \%$ of the most susceptible area of the territory is the model with the lowest area burned explained. It can be verified in the models M4, M5 and M6 that the meteorological variables have a little significant contribution to prediction rates. This finding 


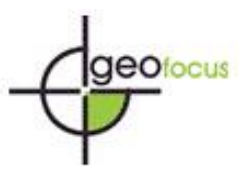

Mileu, N., \& Sargento, B. (2021). Is it possible to map wildfire susceptibility in Madeira Island? GeoFocus, Revista Internacional de Ciencia y Tecnología de la Información Geográfica (Artículos), 28, 5-23. http://dx.doi.org/10.21138/GF.692

was verified by other authors (Verde and Zêzere, 2010), where it was stated that the meteorological variables do not play a significant role in the wildfire susceptibility models.

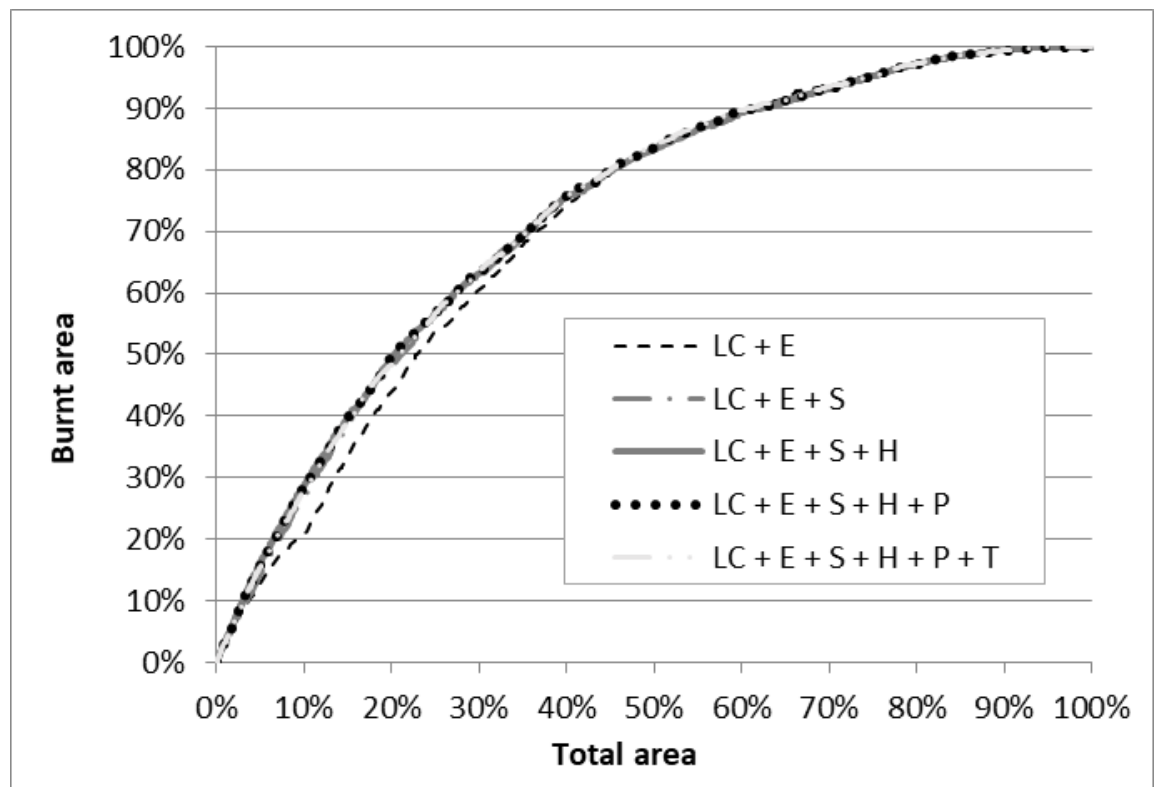

Figure 8. Success rate curves of wildfires susceptibility models.

Analysing Table 3, it can be seen that the model produced with 5 variables, which obtained the best success rate $(0.733)$, explains the highest percentage of burned areas $(75.28 \%)$ in $40 \%$ of the most susceptible area of the territory. However, with more susceptible area processed, this model loses explanatory capacity when compared to other models that uses less variables. Once again, it is hard to distinguish clearly significant differences in the susceptibility models produced.

Table 3. Success rates of susceptibility models.

\begin{tabular}{lccccccccc}
\hline \multicolumn{1}{c}{ Area } & $\mathbf{1 0} \%$ & $\mathbf{2 0} \%$ & $\mathbf{3 0} \%$ & $\mathbf{4 0} \%$ & $\mathbf{5 0} \%$ & $\mathbf{6 0} \%$ & $\mathbf{7 0} \%$ & $\mathbf{8 0} \%$ & $\mathbf{9 0} \%$ \\
\hline $\mathrm{LC}+\mathrm{E}$ & $21.37 \%$ & $43.32 \%$ & $60.20 \%$ & $73.71 \%$ & $83.92 \%$ & $89.20 \%$ & $\mathbf{9 3 . 5 7} \%$ & $\mathbf{9 7 . 2 9} \%$ & $99.31 \%$ \\
$\mathrm{LC}+\mathrm{E}+\mathrm{S}$ & $26.55 \%$ & $47.36 \%$ & $62.87 \%$ & $74.93 \%$ & $83.39 \%$ & $88.91 \%$ & $93.10 \%$ & $\mathbf{9 7 . 1 2} \%$ & $\mathbf{9 9 . 3 2} \%$ \\
$\mathrm{LC}+\mathrm{E}+\mathrm{S}+\mathrm{H}$ & $\mathbf{2 7 . 7 4} \%$ & $48.47 \%$ & $62.67 \%$ & $75.18 \%$ & $83.15 \%$ & $89.24 \%$ & $92.99 \%$ & $97.07 \%$ & $99.31 \%$ \\
$\mathrm{LC}+\mathrm{E}+\mathrm{S}+\mathrm{H}+\mathrm{R}$ & $27.42 \%$ & $\mathbf{4 8 . 4 8} \%$ & $\mathbf{6 3 . 0 8} \%$ & $\mathbf{7 5 . 2 8} \%$ & $\mathbf{8 3} .65 \%$ & $89.36 \%$ & $93.25 \%$ & $97.07 \%$ & $99.31 \%$ \\
$\mathrm{LC}+\mathrm{E}+\mathrm{S}+\mathrm{H}+\mathrm{R}+\mathrm{T}$ & $26.66 \%$ & $47.93 \%$ & $62.90 \%$ & $74.99 \%$ & $\mathbf{8 3 . 7 0} \%$ & $\mathbf{8 9 . 5 8} \%$ & $93.34 \%$ & $97.11 \%$ & $99.29 \%$ \\
\hline
\end{tabular}

In wildfire susceptibility mapping, the determination of model accuracy is typically based on prediction curves. Prediction curves are made with a subset (statistical significant) of burnt areas that were not used in the models, and therefore having no direct relation with the model results allowing for an independent validation. In this work the prediction curves were not calculated since 


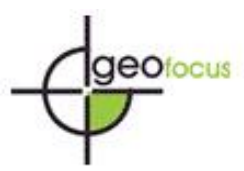

Mileu, N., \& Sargento, B. (2021). Is it possible to map wildfire susceptibility in Madeira Island? GeoFocus, Revista Internacional de Ciencia y Tecnología de la Información Geográfica (Artículos), 28, 5-23. http://dx.doi.org/10.21138/GF.692

the series of years of the burned areas is very short and have a few atypical years, resulting in week explanatory results.

Due to the difficulty in detecting clear breaks in the success curve, the resulting map of the susceptibility model (M5) was reclassified into 5 classes using the quintiles method, available in QGIS software, in which each class represents approximately $20 \%$ of the susceptible territory.

The spatial distribution of wildfires susceptibility in the Madeira Island presents very clear differences between the North and the South of the island (Figure 9). These differences are strongly associated with the land use type: In the south, where there is a greater diversity of land use, the susceptibility is more expressive, with the presence of extensive areas of eucalyptus forest, pinus pinaster, bushland, scrubland and natural grassland, more favourable to combustion. The very high susceptibility occurs mainly in these areas, mostly above $500 \mathrm{~m}$ altitude where there are steeper slopes. In the north, the susceptibility is mostly medium and low, due to the presence of the Madeira laurel forest, which, according to the history of burnt areas, does not present as much propensity to burn. This evidence may also be related to the fact that the Madeira laurel forest is a protected zone, integrated in the Natura 2000 Network, which can take advantage of other anthropic factors as prevention.. In the North sector of the island the temperatures are lower and the rainfall more frequent, which can influence the humidity levels of the vegetation and consequently unfavourable conditions for the combustion. However the analysis of the susceptibility models did not show a significant influence with the introduction of the meteorological variables. In the coastal strip, the soil is mostly occupied by artificial terrain, agricultural areas and bare rock areas, where susceptibility of wildfire occurrence is very low.

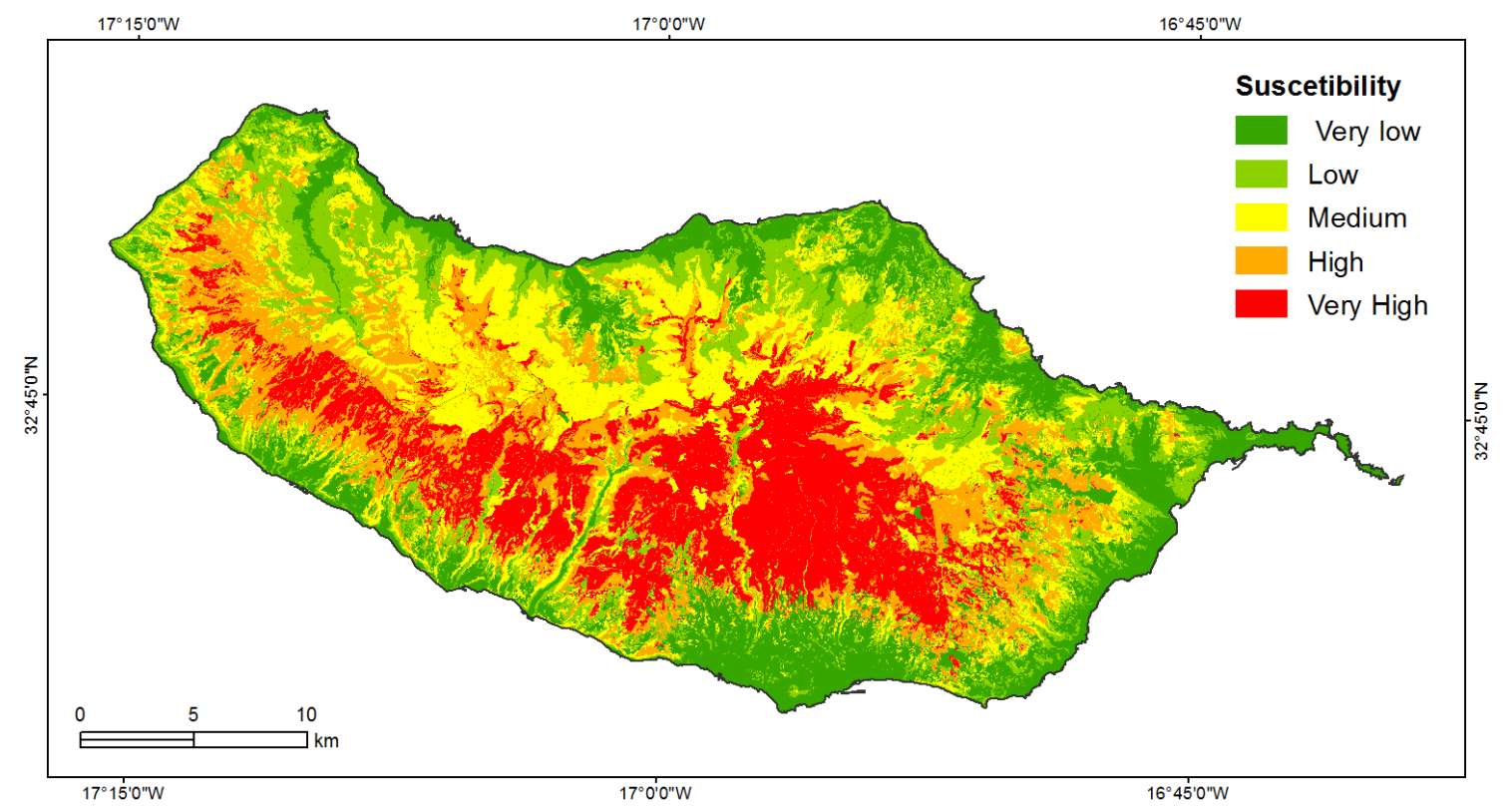

Figure 9. Wildfire susceptibility map in Madeira Island. 


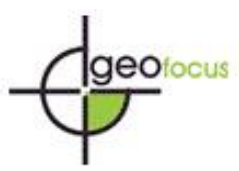

Mileu, N., \& Sargento, B. (2021). Is it possible to map wildfire susceptibility in Madeira Island? GeoFocus, Revista Internacional de Ciencia y Tecnología de la Información Geográfica (Artículos), 28, 5-23. http://dx.doi.org/10.21138/GF.692

\section{Conclusions}

Wildfires are one of the most devastating natural hazards that occur on Madeira Island. Every year wildfires cause considerable economic, social and environmental losses in the Island. As such, it is of utmost importance to investigate their behaviour and identify the most susceptible areas on the Island, in order to promote prevention and fire-fighting actions to mitigate the negative consequences.

Since the updating of the susceptibility maps is a time-consuming and repetitive process, the creation of an automation tool proved to be very useful. In a first phase, it was possible to perform a sensitive analysis using separately the different variables, and then joining the variables one by one based on a hierarchy of results. The automation tool allowed obtaining the susceptibility maps and the validation outputs very quickly when compared to traditional approaches. On the other hand, the tool was developed as open-source software, which enables its reuse and evolution in the QGIS user community. The plugin is still in a test phase, but we hope that it will integrate the QGIS repository soon.

Regarding the different models of susceptibility produced, the results were always unsatisfactory, with an area under the curve always below 0.75 . The different combinations of variables resulted in slightly significant increases in the area under the curve. Overall, the model 5 (M5) model has the best success rate. Possible justifications for unsatisfactory results may be related to the reduced number of years with burnt areas, inclusion of atypical year as 2010, or with the quality and accuracy of data.

According to the technical report of the regional forest management plan (DRFCN, 2015) there is a clear tendency for meteorological conditions to be the main determinant of the size of forest fires. These conditions refer to low relative humidity, high temperatures and strong winds. However, the meteorological variables inclusion in the wildfire susceptibility model did not bring enough value to be considered as determinant in susceptibility assessment and mapping.

Although the robustness of the results is not the best, it has been shown that it is possible to obtain wildfire susceptibility maps for the island of Madeira, enabling its use both in spatial planning and in emergency planning. It was also possible to verify what points to improve in the elaboration of a new wildfire susceptibility map. In future studies, it would be interesting to repeat the assessment with a larger series of years and with more accurate data to evaluate the differences.

\section{References}

Bonazountas, M., Kallidromitou, D., Kassomenos, P.A., Passas, N., (2005). Forest fire risk analysis. Hum. Ecol. Risk Assess. 11, 617-626. https://doi.org/10.1080/10807030590949717.

Catry, F.; Rego, F.; Bação, F.; Moreira, F. (2010). Modeling and mapping wildfire ignition risk in Portugal. International Journal of Wildland Fire, 18, 921-931.

Chuvieco E, Salas J (1996). Mapping the spatial distribution of forest fire danger using GIS. International Journal of Geographic Information Systems. 10, 333-345. doi:10.1080/026937996138070 
Mileu, N., \& Sargento, B. (2021). Is it possible to map wildfire susceptibility in Madeira Island? GeoFocus, Revista Internacional de Ciencia y Tecnología de la Información Geográfica (Artículos), 28, 5-23. http://dx.doi.org/10.21138/GF.692

Chuvieco, E., Aguado, I., Yebra, M., Nieto, H., Salas, J., Martín, M.P., Vilar, L., Martínez, J., Martín, S., Ibarra, P., de la Riva, J., Baeza, J., Rodríguez, F., Molina, J.R., Herrera, M.A., Zamora, R., (2010). Development of a framework for fire risk assessment using remote sensing and geographic information system technologies. Ecol. Model., 221, 46-58. https://doi.org/10.1016/j.ecomodel.2008.11.017

Chuvieco, E.; Congalton, R. (1989). Application of remote sensing and geographic information systems to forest fire hazard mapping. Remote sensing of Environment, 29, 147-159.

DRFCN - Direção Regional de Florestas e Conservação da Natureza (2015). Plano Regional de Ordenamento Florestal da Região Autónoma da Madeira [Regional Plan for the Forestry Management], 1st ed.; Secretaria Regional do Ambiente e Recursos Naturais, Funchal, Portugal (in Portuguese).

Frattini, P.; Crosta, G.B.; Carrara, A. Techniques for evaluating the performance of landslide susceptibility models. Eng. Geol. 2010, 111, 62-72.

Goldammer, J.; Ioannis, M.; Mallinis, G.; Woolf, M. (2017). Wildfire Hazard and Risk Assessment. In Words into Action Guidelines - National Disaster Risk Assessment, 1st ed.; Safaie, S., Ed.; United Nations Office for Disaster Risk Reduction: Geneva, Switzerland; Part three, 6.

González-Calvo, A.; Hernández-Leal, P. A.; Alonso-Benito, A.; Arbelo, M. \& Arvelo-Valencia, L. (2008): Modelado del riesgo de incendios forestales en las Islas Canarias usando datos de satélite y aplicaciones SIG. En: Hernández, L. y Parreño, J. M. (Eds.), Tecnologías de la Información Geográfica para el Desarrollo Territorial. Servicio de Publicaciones y Difusión Científica de la ULPGC. Las Palmas de Gran Canaria. Pp. 588-596. ISBN: 978-84-96971-53-0.

González-Calvo, A.; Hernandez-Leal, P.; Arbelo, M. \& Arvelo-Valencia, L. (2007). Evaluación del riesgo de incendios forestales en las Islas Canarias usando datos AVHRR y MODIS, Teledetección - Hacia un mejor entendimiento de la dinámica global y regional, Ed. Martin. ISBN: 978-987-543126-3.

IGP (2007). Cartografia de risco de incêndio florestal dos Distritos de Aveiro, Braga, Bragança, Coimbra, Guarda, Portalegre, Porto, Viana do Castelo, Vila Real e Viseu e Projecto de elaboração das CRIF a nível nacional, Instituto Geográfico Português, Ministério do Ambiente, do Ordenamento do Território e do Desenvolvimento Regional, Lisboa. http://scrif.igeo.pt/documentacao/forma\%E7\%E3o_09-04-07.zip (Downloaded December 2019).

Jaiswal, R.K., Mukherjee, S., Raju, K.D., Saxena, R. (2002). Forest fire risk zone mapping from satellite imagery and GIS. Int. J. Appl. Earth Obs. Geoinf., 4, 1-10. https://doi.org/10.1016/S03032434(02)00006-5.

Jebur, M.; Pradhan, B.; Shafri, H.; Yusoff, Z. and Tehrany, M. (2015). An integrated user-friendly ArcMAP tool for bivariate statistical modelling in geoscience applications. Geosci. Model Dev., 8, 881-891. doi:10.5194/gmd-8-881-2015

Leuenberger, M.; Parente, J.; Tonini, M.; Pereira, M. and Kanevski, M. (2018). Wildfire susceptibility mapping: Deterministic vs. stochastic approaches, Environmental Modelling \& Software, 101, 194-203. https://doi.org/10.1016/j.envsoft.2017.12.0191364-8152/ 


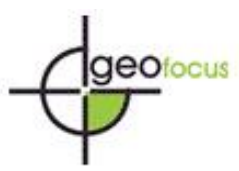

Mileu, N., \& Sargento, B. (2021). Is it possible to map wildfire susceptibility in Madeira Island? GeoFocus, Revista Internacional de Ciencia y Tecnología de la Información Geográfica (Artículos), 28, 5-23. http://dx.doi.org/10.21138/GF.692

Pereira, J., Santos, M. (2003). Fire Risk and Burned Area Mapping in Portugal. Direcção-Geral das Florestas, Lisboa, 64 p.

Piedade, A.; Zêzere, J.; Garcia, R.; Oliveira, S. (2011). Modelos de Susceptibilidade a Deslizamentos Superficiais Translacionais na Região a Norte de Lisboa. Finisterra, XLVI, 9-26.

Python Software Foundation. Python Language Reference, version 2.7. Available at http://www.python.org.

QGIS Development Team (2018). QGIS Geographic Information System. Open Source Geospatial Foundation. Available at http://qgis.org.

Romero-Calcerrada, R.; Novillo, C.; Millington, J.; Gomez-Jimenez, I. (2008). GIS analysis of spatial patterns of human-caused wildfire ignition risk in the SW of Madrid (Central Spain). Landscape Ecology, 23, 341-354.

Silva, F.; Meneses, C. (1940). Elucidário Madeirense, 2nd ed.; Junta Geral do Distrito Autónomo do Funchal: Funchal, Portugal (in Portuguese).

SRPC - Serviço Regional de Proteção Civil (2015). Plano Regional de Emergência de Proteção Civil da Região Autónoma da Madeira [Regional Civil Protection Emergency Plan], 1st ed.; Secretaria Regional dos Assuntos Sociais, Funchal, Portugal (in Portuguese).

Ventura, J.; Vasconcelos, M. (2006). O fogo como processo físico-químico e ecológico, 1st ed.; ISAPress, Lisbon, Portugal (in Portuguese), pp. 93-113.

Verde, J. (2008). Wildfire Hazard Assessment. M.Sc. thesis, University of Lisbon, Portugal (in Portuguese).

Verde, J. (2015). Wildfire susceptibility modelling in mainland Portugal, $\mathrm{PhD}$ thesis, University of Lisbon, Portugal, http://hdl.handle.net/10451/23641.

Verde, J.; Zêzere, J. (2010). Assessment and validation of wildfire susceptibility and hazard in Portugal. Nat. Hazards Earth Syst. Sci. 2010, 10, 485-497.

Wu, Y., Yin, K.; Liu, Y. (2000). Information analysis system for landslide hazard zonation. In Landslides in Research, Theory and Practice, 1st ed.; Bromhead, E., Dixon, N., and Ibsen, M., Eds.; Thomas Telford: London; 3.

Yin K.; Yan T. (1988). Statistical prediction models for slope instability of metamorphosed rocks. In Landslides, Proceedings of the Fifth International Symposium on Landslides, Balkema, Rotterdam; 1269-1272.

Zêzere, J. (2002). Landslide susceptibility assessment considering landslide typology. A case study in the area north of Lisbon (Portugal). Nat. Hazards Earth Syst. Sci., 2, 73-82. 
